\title{
Beyond Beasts: Some Cases of Native American AniManism
}

\author{
Bijay Kumar Rauniyar \\ Retired Professor of English, \\ Tribhuvan University, Nepal
}

\section{Introduction}

We all are animals and animals (are) us. There is only a thin line between both of us and beasts. We often tend to fall towards the beastly line. This paper, however, will show how the Native American tribes maintain their ties and wisdom with the animals. For them, animal spirits stand for life and livelihood. They regard animals as "the messenger for wisdom about life, nature, and power. These also prophecy future (events), as we take dogs' moaning to herald earthquake and cats' growling to trumpet troubles. The tribes represent those spirits through symbols on clothes, art and ceremonial items as "Traditional Ecological Knowledge," or TEK, in short (Grayson). For example, northern Plains peoples used buffalo images in holy rites and placed its skulls on homes to honor its spirit while others name clans after animals, and use animal amulets, talismans, and fetishes. In Nepal also, some Tharus have Gajaraj(King of Elephants) clan; and Hatti (elephant) is the clan name of a Vaishya caste in Terai. Here Gaindakot, across the Trishuli River, is named so as "a habitat of rhinos" and Chitrawan (Chitwan) after Chitrakut, India and it celebrates the entire flora and fauna along with the humans. Other noteworthy animal place names, among many, are Gaighat (Udaypur), Bayalbas (Sarlahi), Ghodasahan (Bihar, India), Gaushala (Mahottari and Kathmandu), Gauchar(an) (Kathmandu), Singapore (Singapore), and so on. Many deities have animals as their carriers or costumes like snake and tiger skin (Shiva), mouse (Ganesha), and peacock (Saraswati), and many nations have animals as their prominent national symbols like eagle (USA), tiger (India), lion (Sri Lanka). Even some currencies carry animals denoting denominations - for examples, gainda (rhino) means 100.00 NPR, bagh (tiger) stands for 500.00 NPR, and hatti (elephant) is worth 1,000.00 NPR.

\section{Discussions}

Rene Descarte (1641) and his modern industrialized followers, however, call animals as nonhumans, and non-homo sapiens or insentient, "simply automata, with no ability to reason or have an ability for self-awareness" (qtd. Boyd). These exclude pets and zoo animals. But Boyd condemns their commoditization, and general treatment and disregard to those many on farms, fisheries, and pharmaceuticals. But animals do have animism - that is wisdom, conscience, and cosmic sense, and thus command our respect. We Nepalese, especially Hindus respect and reciprocate their wisdom every day by offering some grains to the birds or ausa (food offerings) to nature before every meal. We pray and circumambulate tulsi tree (basil plant) and pray to 
different other plants (for example, mango, banana, bunyan, peepal, sugarcane, amala, etc.) and animals (for instance, pigeons, cows, horses, elephants, and so on) During Tihar we worship crow, dog, cow, and ox for all five days, that is together called Yamapanchak, as saviors and/or carriers to the heaven. Jains (onion and garlic abstainers) and other vegetarians and animal rightists like PETA (People for the Ethical Treatment of Animals) and ADL (Animal Defence League) show high respect for all animals. Indigenous and native Nepalese, Chinese, Tibetans, and other Mongoloids celebrate their festivals and New Years (e.g. Lhosars) in the name of nature and animals like dog, monkey, horse, and so on. We also observe Cow and Horse Festivals (Gai Jatra, Ghode Jatra, etc.). And the legend has it that one of the seven Buddhas that were born in Nepal offered his body to a starving tiger so that the latter could survive, and the last one-Siddhartha Gautam Buddha - paid tribute to him by greeting as "Namo Buddhaya" (Hail Buddha).

\section{Narrations}

Before moving to Native Americans' stories of human-animal harmony, I hereby cite some of their stories of interspecies and intraspecies conflict. For example, "Puma and the Bear" tells us about Puma's conflict with the Bear as the latter elopes with his wife. Puma and his son fight with the Bear, break its back on a rock, and retrieve the lady. But Puma sends the unfaithful woman to the woods, and together with his son leaves "on another hunting trip to find a new wife and home for themselves" (Welker). In "Porcupine Hunts Buffalo," Welker narrates how a Porcupine tricks the buffalo far across the river by riding inside its belly and tearing its heart with its heavy tail. He butchers the buffalo with a Coyote's help who gives it the belly part and asks to go wash it but forbids him to eat it. The Porcupine defies the Coyote and so the latter kills him, and informs its family of its hunt. Meanwhile, the Porcupine, through his earlier wish inside the buffalo's belly makes a red pine grow there and comes magically alive. He perches atop and kills the entire coyotes, except the young one, gathered below. Then he and the baby coyote go home and together hunt buffalo. The third story, "Two Grandsons," tells us how the grandfather retrieves the youngest boy's body from the meat of an elk that the boy had given to a jungle man and who had killed him. The grandfather does so by making the older boy take the meat out of the man's teeth and pile it. Early next morning the boy comes alive. Below I cite examples of Native Americans' good relations with animals, understanding their behavior, and respecting them for the human traits and wisdom.

\section{Illustrations}

Native Americans like Utes (especially women) also take part in Bear Dance to increase their hunting and virility, and to instill the same spirit in the now "grown-up" girls. They also participate in the Sun Dance for individuals or community (barrio). These Red Hoods, thus, retain their native or Uterine "redhood," orality, and posterity. Ute men mark their puberty by hunting but not dining deer. Women, too, mark it avoiding deer meat and some other activities (Ute Encyclopedia). These and other hunter-gatherer societies regard animals as sapiens and 
show respect even while hunting them. They believe that both human and non-human forms moved and evolved together and harmoniously and, therefore, humans should retain mutual respect, nature kinship, and conviviality (Boyd).

The Yup'ik Eskimo of Alaska, likewise, call animals as non-human persons (Grim). So do the Haisla and Henaksiala peoples of Northwest British Columbia (Harris, qtd. Boyd). Both tribes base their worldview on the perennial ties between the two. They also believe that the animals only give themselves to the respecting hunters. Together these immortal souls undergo birth, death, and rebirth. Self-aware, both can carve and control their own destinies. Most significantly, humans are just a group of persons among a larger group of persons - that is animals. According to Harris, a mountain goat disguised/incarnated as a human showed a hunter the animals' personhood (qtd. Boyd). The Gwich'in indigenous population of Northern Canada and Alaska also believe that both humans and non-humans can exchange forms. According to a legend, a Caribou remained a human before returning to its animalhood; a human, too, lived like a Caribou for a year (Gwich'in Elders). They, therefore, use every hunt wisely, treat or keep alive a hurt one, and avoid stepping in its blood if killed or dead.

The Rock Cree, according to Brightman, also believe that animal souls give themselves up to the hunters as per their regards to themselves and their bones and blood. Their and other huntergatherers' women, too, abstain from some activities, particularly during adolescence, menstruation, and pregnancy for the hunter-gatherers' success and their own fertility. Cree women, however, often snare small game, fish and furbearers, and hunt even moose, caribou and bears. Even their men boast of the spouses' achievements. All regard women especially lucky as trappers of martens (Brightman).

Some hunter-gatherers interact with wild animals as free and equals. The settlers and herders, however, control them. This owes to urbanity, modernity, and mercantility [my coinage/emphasis]. Bulliet explains it better.

Wild species that might earlier have been considered ancestors or embodiments of sacredness were increasingly classified as predators (on humans and their domestic livestock), quarry for human hunts, competitors for space and resources, vermin, or spectacles for observation as captives or in staged fights. The more sophisticated categories and conceptions of animals, together with the expert knowledge of nature that went with them, lived on in the groups that refused, sometimes down to the present day, to make use of the domestic species they had access to. But people living in domesticity generally looked down upon people living in pre-domesticity.

Nuer (Evans-Pritchard) and Sebei (Goldschmidt), for instance, castrate and commoditize bullocks. The latter even doubt that animals have any souls or spirits. They hegemonize humans over cattle though they believe that the latter can understand, if not speak, words, and see them as competitors, and therefore, must be annihilated. On the contrary, Beyond Beasts: Some Cases 
of Native American AniManism researchers like Lemieux, Bekoff, and European Commission find dolphins, pigs, and cattle respectively quite sentient and self-aware while Boyd finds species like Beluga whale in the Arctic highly familial and emotional. In the last case, many whales waited till the adolescent was rescued, and cheered when it swam back to them. These instances tie the human-animal knot tighter and more humanely and personally while whetting interests in "animal theology" beyond bands and clans (Aftandilian 193). We, too, must rise beyond the "beast" that resides in us, and often threatens to goad out of our spirits. Yes, rise, be the animalperson, move towards the sublimity, meet the Ultimate, and complete the life-cycle that we get only once in an era. Most importantly, we must show "humility and respect" (Lewis and Jordan 118) to our stronger predecessors or foremost fore-fathers, and promote AniManism rather than sheer humanism.

\section{Works Cited}

Aftandilian, Dave. "Toward a Native American Theology of Animals: Creek and Cherokee Perspectives." CrossCurrents, Vol. 61, No. 2, "Trees, Forests, Animals, Ooutlaws and Other: Theology Rarely Touches" (June 2011), pp. 191-207.

Bekoff, Marc. "Animal Emotions: Do animals think and feel?" Psychology Today, 2011. July 09, 2013. Web. Jan. 26, 2019. www.psychologytoday.com/blog/animalemotions/ 201110/babe-lettuce-and-tomato-dead-pig-walking.

Boyd, Roger. "The Indigenous and Modern Relationship Between People and Animals." Humanity's Test, January 17, 2014. Web. Feb. 26, 2019. www.resilience.org/stories/2014-01-17/the-indigenous-and-modern-relationshipbetweenpeople-and-animals/.

Brightman, Robert A. Grateful Prey: Rock Cree Human-Animal Relationships. University of California Press, 1993. Web. Jan. 27, 2019. www.ark.cdlib.org/ark:/13030/ft0f59n6tb/.

Bulliet, Richard W. Hunters, Herders, and Hamburgers: The Past and Future of Human-Animal Relationships. Columbia University Press, 2005. Web. Feb. 03, 2019. www.jstor.org/stable/10.7312/bull13076.

Descartes, Rene. Mediations on First Philosophy. Hackett Publishing Company, 1641 (1993 translation). Web. Dec. 26, 2018. www.hackettpublishing.com/meditations-onfirstphilosophy.

EU Scientific Committee on Animal Health and Animal Welfare. The Welfare of Cattle kept for Beef Production. European Commission, 2001. Web. Jan. 15, 2019. www.ec.europa.eu/food/sites/food/files/safety/docs/sci-com_scah_out54_en.pdf. 
Evans-Prichard, E. E. The Nuer: A Description of the Modes of Livelihood and Political Institutions of a Nilotic People. Oxford University Press, 1940. Web. Feb. 16, 2019. www.archive.org/stream/nuerdescriptiono00evan/nuerdescriptiono00evan_djvu.txt.

Goldschmidt, Walter. Culture and Behavior of the Sebei: A Sudy of Continuity and Adaptation. University of California Press, 1976. Web. Dec. 25, 2018. www.researchgate.net/publication/263133520_Walter_Rochs_Goldschmidt_1913-2010.

Grayson, Lee. "The Native American Spiritual Meanings of Animals." Sciencing, April 25, 2017. Web. Feb. 25, 2019. www.sciencing.com/native-american-spiritual-meaningsanimals6093.html.

Grim, John. Indigenous Traditions and Ecology. Harvard Center for the Study of World Religions, 2001. Web. Nov. 19, 2018. www.hup.harvard.edu/catalog.php? $i s b n=9780945454281$.

Gwich'in Elders. Nanh'Kak Geenjit Gwich'in Ginjik: Gwich'in Words about the Land.Gwich'in Renewable Resource Board, 1997. Web. Dec. 31, 2018. www.pubs.aina.ucalgary.ca/arctic/Arctic66-1-68.pdf.

Harris, Ken. Legend of the Hunter. n.a., 2002. In Boyd. Lemieux, Leah. Rekindling the Waters: The Truth about Swimming with Dolphins. Troubadoe Publishing Limited, 2009. Web. Jan 29, 2019. www.resilience.org/stories/2014-01-17/the-indigenous-and-modernrelationship-between-people-and-animals/.

Lewis Jr., David, and Ann T. Jordan. Creek Indian Medicine Ways: The Enduring Power of Mvskoke Religion. University of New Mexico Press, 2002.

Ute Encyclopedia of World Cultures. The Gale Group, 1996. Web. Oct. 15, 2018. www.encyclopedia.com/history/united-states-and-canada/north-americanindigenouspeoples/ ute.

Welker, Glenn, (comp.). "Puma and the Bear." February 8, 1996. Web. Jan. 01, 2019. www.indigenouspeople.net/pumabear.htm.

"Porcupine Hunts Buffalo." February 8, 1996. Web. Jan. 04, 2019. www.indigenouspeople.net/porcbuff.htm.

• "Two Grandsons." February 8, 1996. Web. Jan. 11, 2019. www.indigenouspeople.net/twogrand.htm. 